\title{
ASSESSMENT MODEL OF REGIONS' COMPETITIVE ADVANTAGE BASED ON STATISTICAL DATA AND INDICATOR ANALYSES
}

\author{
Krystyna CZAPLICKA-KOLARZ ${ }^{1}$, Mariusz KRUCZEK ${ }^{2}$, Małgorzata MARKOWSKA ${ }^{3}$ \\ ${ }^{1}$ Silesian University of Technology, Faculty of Organization and Management; \\ krystyna.czaplicka-kolarz@ polsl.pl, ORCID: 0000-0002-4695-215X \\ ${ }^{2}$ Central Mining Institute; mkruczek@ @ig.eu, ORCID: 0000-0002-5052-3729 \\ ${ }^{3}$ Central Mining Institute; mmarkowska@ gig.eu, ORCID: 0000-0002-9105-6856 \\ * Correspondence author
}

Purpose: The aim of the article is to present a conceptual model for the assessment of competitive advantage of the region referring to smart specialization.

Design/methodology/approach: For the purpose of developing the model, a literature review of the competitive advantage was conducted. Then the main statistical indicators necessary to assess the competitiveness of the region were selected. These indicators included data on economy, research and patents. Indicator data are a source of information for experts to conclude on the competitive advantage of the region and areas of potential specialisation. Pilot studies for the developed model were carried out in the Silesia Voivodeship.

Findings: The main result of the work was to develop a model for assessing the competitiveness of the region in the context of smart specialisations. The model based on statistical data and expert opinions and is a useful tool for selecting and updating specialization.

Research limitations/implications: It was noted that relying only on statistical data to assess a region's level of competitiveness is not sufficient, as these are provided with some delay. In addition, these data usually represent a high level of aggregation.

Practical implications: The developed model finds practical application in the process of identifying and updating smart regional specialisations. It can be used by local governments to build a regional innovation policy.

Social implications: Intelligent specialisations are key components of regional development. They influence economic, social and environmental aspects. The use of the model in the Silesian Voivodeship has made it possible to distinguish a new smart specialisation which is green economy.

Originality/value The article contribute to realization of the entrepreneurial discovery process in the regions, which is, according to the guidelines of the European Commission, the main component of the innovation development policy.

Keywords: the competitiveness of the region, entrepreneurial discovery process, evidencebased policy.

Category of the paper: Conceptual paper. 


\section{Introduction}

Recent years have been associated with radical changes in the factors of socio-economic development of regions. The dynamics of these changes is so substantial that it is increasingly difficult to track changes in order to capture cause and effect relationships between individual elements. This is why, the focus of researchers' attention has been on information resources, economic knowledge and, in particular, innovation, not only at international and/or national level, but more often than not at regional and local level. Regions are now a key platform for development and shaping economic and innovation policy. In the regions there are processes of creation, absorption and diffusion of innovations. Knowledge of the pro-innovative potential of the region and of the needs of the economy is a necessary condition for building its innovative capacity. In order for these processes to take place, it is vital to develop mechanisms of competitive advantage assessment, which would provide up-to-date information on the need to adapt regional entities to changing conditions through development of existing and new competences, building network relations, etc. The process that makes these challenges viable is entrepreneurial discovery, which, however, has not been included in a formal framework and is implemented in each region individually. The article presents the concept of a model for the assessment of competitive advantages of the region based on the experience from the entrepreneurial process of discovering in Poland, especially in the Silesia Voivodeship. The article presents a holistic approach to the process of assessment and development of the competitive potential of regions based on statistical data and indicator analyses.

\section{Nature and concept of regional competitiveness}

The concept of competitiveness is used in different contexts and relates to companies, sectors, regions, countries and transnational organisations. Business competitiveness is a concept strictly linked to management sciences and is well-known at this level, with much greater complexity for competitiveness research at regional and/or national level. Differences in the objectives of achieving competitive advantages as well as in the characteristics of regions and businesses make the competitiveness category take on a new meaning. According to M.E. Porter (2006), the concept of competitiveness of nations is hard to define, and the attempt to assess it synthetically for the whole nation (state) as such is particularly complex. Figure 1 shows the different levels of competitiveness. 


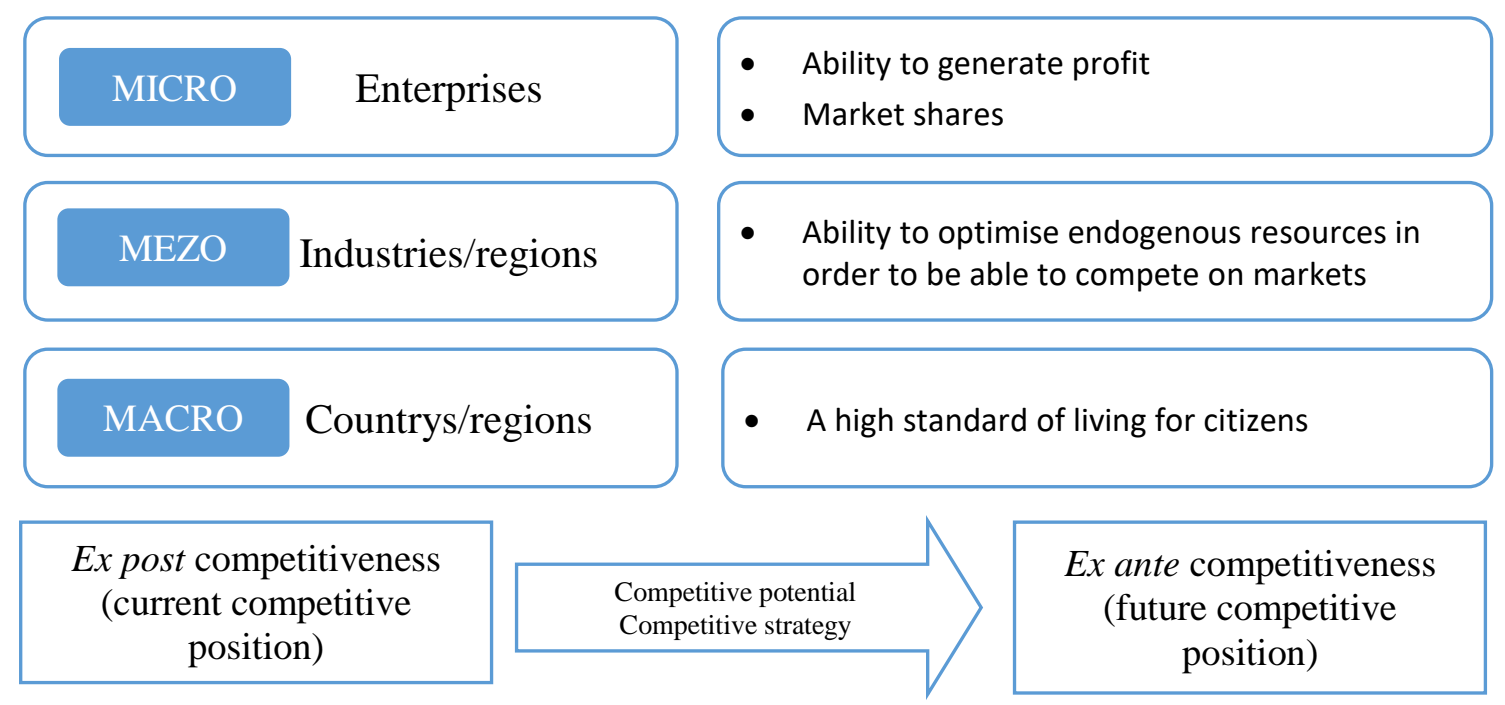

Figure 1. Competitiveness levels Adapted from: Regional competitiveness. Concepts - strategies examples, ed. E. Łaźniewska, M. Gorynia, WN PWN, Warsaw 2012, p. 27.

If it is assumed that the main objective of the region/state is to raise the standard of living of the population, this objective can be achieved by effective use of labour and capital resources concentrated on the local market (Góralski, Lazarek, 2009). Efficiency in this way is understood as a result in relation to activities undertaken by individual businesses, but it is not a simple sum of individual effectiveness, because the environmental conditions created by the administration, access to R\&D\&I resources and cooperation allow to create a high and growing standard of living for the society, which is an objective of competitiveness at the regional/national level. In addition, regional competitiveness is fostered by a number of strategies and instruments which may take on various forms and affect different regions (Dijkstra et al., 2011). A slightly different view on competitiveness is presented by the World Bank Group, where competitiveness is identified with productivity. In this way, competitiveness refers to the added value generated per unit of resources engaged. This approach has resulted in treating competitiveness as a constant process of creating and implementing innovation and strengthening and improving those factors and activities that determine the amount of added value generated (Khemani, Shapiro, Stanbury, 1988). This definition is strictly factorial and its main advantage is that it emphasises the role of innovation in creating and maintaining competitiveness.

OECD (Hatzichronoglou, 1997) uses a very general concept of competitiveness, which is treated as 'the ability of companies, industry, regions, nations or supranational regions to generate relatively high revenues and high levels of employment in the long term under conditions of international competition'. This approach is of a resultant nature and applies to both companies and regions/countries. The disadvantage of this approach is that the assessment of the competitive position is static and not prospective, which would take into account trends and changes in the future. 
The analysis of the competitiveness concept related to the regional/country level therefore is focused on the assessment of economic performance (based on international comparisons) and the identification of the sources of the economic position achieved (Turok, 2004). The sources of advantage include human resources, capital, technologies, innovativeness, as well as factors determining the allocation of these resources and their creation, such as regulations and economic policy. Their more in-depth analysis leads to the conclusion that, in practice, economic competitiveness analysis is a specific approach to economic growth analysis (Radło, 2010). When considering the level of competitiveness of regions, importance is usually attached to their economic strength. According to G. Gorzelak (1997), it is estimated that economic strength is determined on the basis of the amount of public income created in the regions. For this reason, it is commonly believed that the following factors are responsible for competitiveness: diversification of the region's economic structures, communication accessibility, existing research and development base, existing business environment institutions (Góralski, Lazarek, 2009).

In the light of the aforementioned definitions, there is a need to accentuate the competitive position of the region in the context of the implementation of national/regional innovation strategies for smart specialisation (RIS3 strategies), which are integrated, local economic transformation programmes aimed at:

- ensuring knowledge-based development by targeting policy support and investment towards key national or regional challenges and needs,

- utilising the strengths, competitive advantage and potential for excellence of each country/region,

- fostering technological innovation and stimulating private sector investment,

- the full involvement of partners and encouragement of innovation and experimentation,

- building a region/country advantage based on evidence-based policy and developing appropriate monitoring and evaluation systems.

The concept of smart specialisation appeared for the first time in the work of Foray and others (2015), where it was defined as an entrepreneurial process of identifying the areas of science and technology from specialisation in which a selected region can benefit (Figure 2). 


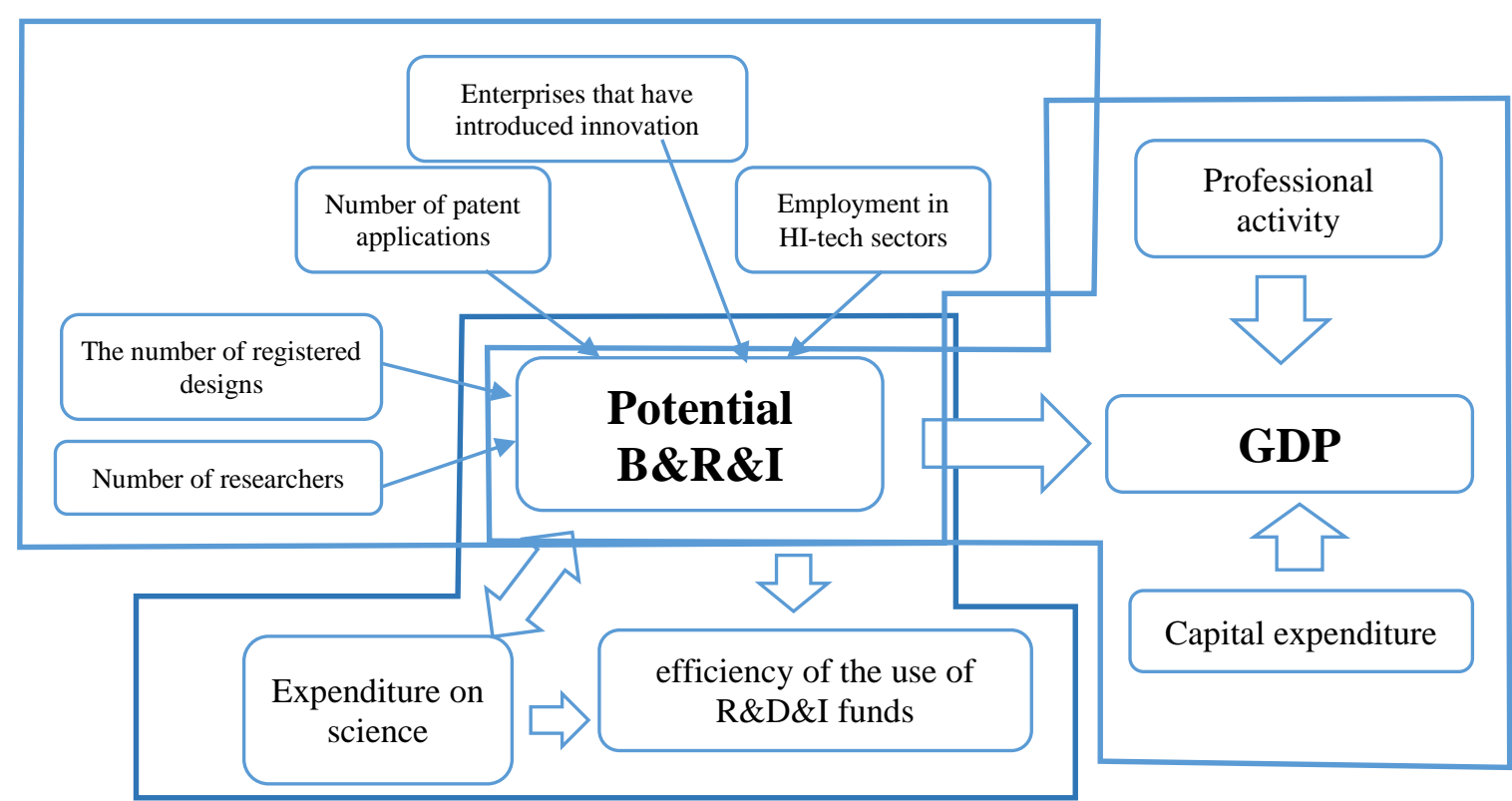

Figure 2. R\&D\&I potential as an element determining the competitive advantage Adapted from: Method of determining the endogenous potential of the region and the country based on a mathematical, statistical and econometric model, report on the work of the National Foresight Programme implementation of results, Central Mining Institute, Katowice, 2013.

Nowadays, despite the lack of theoretical foundations for the concept, it is a key element in building innovation in regions and evaluating their potential and competitiveness. The European Union has established a smart specialisation as the backbone of the 'Europe 2020' flagship initiative called 'Innovation Union'. European Union documents do not mention smart specialisation so much as smart specialisation strategy. However, the search for smart specialisation that can become a source of competitive advantage is a tough challenge for regions (Capello, Kroll, 2016). The very essence of smart specialisation indicates that the competitive advantage of a region is an area in which the region has a larger-than-average concentration of factors in comparison with other regions of the country or with other countries. One of the most crucial factors determining this advantage is the potential of the R\&D\&I sphere.

\section{Conceptual model for assessing the competitiveness of regions}

According to the literature on the subject (Łaźniewska, Chmielewski, Nowak, 2012), regional competitiveness can be measured and evaluated in two ways:

- by breaking down the overall competitiveness into identified competitiveness factors,

- by developing specific and synthetic indicators and competitiveness measures. 
The competitiveness measured today is the result of many economic phenomena, social processes and development policies, but it certainly does not result from the previously defined smart specialisation, which makes it considerably more difficult to define the boundaries of measurement of competitiveness and to determine the path to it. In addition, future smart specialisation will not be the only source of growth in the region's competitiveness, as this growth is made up of various social and economic phenomena, random events, etc. (Oughton, Landabaso, Morgan, 2002). Therefore, it is virtually impossible to build a simple algorithm describing the progress in specialisation and its impact on the increase in competitiveness. Hence, the competitiveness assessment model should be based on breaking down the factors of many factors affecting the competitiveness of regions. The possibility of competitive advantages in particular fields, i.e., possible specialisation, is concluded on the basis of comparisons of the state/trends of a given factor with trends in other regions, because the synthetic indicators/measures relating to the competitiveness of a region do not indicate any specialisation directions or market niches. Methods aimed at breaking down competitiveness into identified competitiveness factors, of which usually one of the most relevant is the research and technological development of the region, include the following theoretical models (Łaźniewska, Chmielewski, Nowak, 2012):

- the competitiveness pyramid,

- the competitiveness hat,

- the competitiveness tree,

- the Porter's model.

The competitiveness pyramid (Misztal, 2009) is one of the most frequently used models used to describe regional competitiveness. The concept developed by the European Commission in 1997 presents the factors determining the level of competitiveness achieved. It is a proposal for a systematic approach to their classification, taking into account both indirect and direct factors. The competitiveness pyramid presents the factors determining the level of competitiveness achieved, related mainly to the standard of living, employment level and productivity of manufacturing factors. In this model, the division and interdependencies are particularly clearly marked between:

- sources of competitiveness, i.e., factors that affect competitiveness in the long run, among which the most crucial are social and economic factors (including the culture of innovation),

- development factors, also known as disclosed competitiveness,

- targeted outcomes, with categories such as standard of living and well-being as basic outcomes. Therefore, at the top of the pyramid there is an indicator of the quality of life measured by the GDP per capita.

- The competitiveness hat model developed by Cambridge Econometrics and ECORYSNEI on behalf of the Directorate-General for Regional Policy of the European Commission (Martin, 2003). It consists of several levels (Nowak, 2011): 
- regional performance, where the distinctive indicator is GDP per capita;

- results/performance of the region, defined by regional added value and factors such as unit labour costs, profitability, market shares;

- market structure dependent on sectors operating in the region, specialisation, companies' distribution and their ownership;

- the determinants of regional competitiveness, constituting a group of factors in which traditional factors of production such as capital, labour and land have been replaced by basic infrastructure, human resources and production environment. The components of these factors are such characteristic features of a given region as institutions, technologies, innovation, entrepreneurship, internationalisation, social capital, knowledge infrastructure, culture, demography and migration, quality of the place and the environment.

For the purpose of better illustration of the complex relationships shaping the competitiveness of different places, in 2004, ECORYS-NEI developed a competitiveness tree model. This model is meant to be a tool for policy formulation (Laźniewska, Chmielewski, Nowak, 2012).

Porter's competitiveness analysis model (2003) (called Porter's diamond) is made of four groups of mutually interdependent factors determining, at the microeconomic level, the creation of a competitive advantage of a region:

- production factors (e.g., human, capital and natural resources, technical, administrative, scientific, technological and IT infrastructure),

- the specifics of the national or regional demand,

- the presence of competitive industries in the region,

- the companies' strategy, the way they manage and compete.

\section{Table 1.}

Comparison of competitiveness factors in the competitiveness hat model, competitiveness pyramid and Porter's diamond model

\begin{tabular}{|c|c|c|}
\hline The model name & $\begin{array}{l}\text { Factors determining the } \\
\text { competitive position }\end{array}$ & Factors indicating competitive potential \\
\hline $\begin{array}{c}\text { The competitiveness } \\
\text { pyramid model }\end{array}$ & $\begin{array}{l}\text { - GDP, } \\
\text { - Productivity, } \\
\text { - Employment. }\end{array}$ & $\begin{array}{l}\text { - employment structure, } \\
\text { - innovation culture, } \\
\text { - regional accessibility, } \\
\text { - employee skills, } \\
\text { - social structure, } \\
\text { - decision-making centres, } \\
\text { - quality of the environment, } \\
\text { - social cohesion of the region, } \\
\text { - foreign trade activity. }\end{array}$ \\
\hline
\end{tabular}


Cont. table 1 .

\begin{tabular}{|c|c|c|}
\hline $\begin{array}{c}\text { The competitiveness } \\
\text { hat model }\end{array}$ & $\begin{array}{l}\text { - GDP per capita, } \\
\text { - Gross value added. }\end{array}$ & $\begin{array}{l}\text { - unit labour costs, } \\
\text { - } \text { profitability, } \\
\text { - } \text { sectoral structure of the market, } \\
\text { - infrastructure, } \\
\text { - } \text { technolitutions, } \\
\text { - innovativenes, } \\
\text { - entrepreneurship, } \\
\text { - human resources, } \\
\text { - knowledge infrastructure, } \\
\text { - } \text { culture, } \\
\text { - demography and migration, } \\
\text { - } \text { quality of the place, } \\
\text { - internationalisation, } \\
\text { - production environment, } \\
\text { - environment. }\end{array}$ \\
\hline $\begin{array}{l}\text { The Porter's diamond } \\
\text { model }\end{array}$ & $\begin{array}{l}\text { Assessment of the } \\
\text { competitiveness } \\
\text { development stage } \\
\text { (resources, investment, } \\
\text { innovation, wealth) }\end{array}$ & $\begin{array}{l}\text { - production factors, } \\
\text { - nature of domestic demand, } \\
\text { - the presence of competitive industries, } \\
\text { - the companies' strategy, the way they } \\
\text { manage and compete, } \\
\text { - the government's role, } \\
\text { - random events. }\end{array}$ \\
\hline
\end{tabular}

Adopted from: Łaźniewska E., Chmielewski R., Nowak P., Definitions, models and studies on the regional competitiveness (in:) E. Łaźniewska, M. Gorynia (ed.) Regional competitiveness. Concepts strategies - examples, PWN Polish Scientific Publishers, Warsaw 2012.

The analysis (Table 1) suggests that most of the models aim at analysing the growth potential affecting future opportunities, rather than what has already been done, and the developed assessment model should therefore examine the trends in the development of the innovation potential of the regions and anticipate the impact of changes in the innovation potential on the economic growth of the region. The analysis of competitive capability in the described models is made on the basis of variously classified factors related both to the assessment of the local strategy and the assessment of the environment in which businesses or regions operate. In fact, all the competitiveness analysis models described are based on the consideration of the effects of different factors on the creation of national income and, in this sense, they are a sort of specific approach to economic growth analysis.

For the sake of work on the model of assessment of the region's competitiveness, only some of the sources determining it were analysed and the elements of the revealed competitive advantage were selected. The model was additionally included in the processes of entrepreneurial discovery which enable the utilisation of available data and indicators concerning the potential of the R\&D\&I sphere to identify development niches that may be the source of competitive advantage of the region. The process of entrepreneurial discovery is a continuous process aimed at identifying areas with the potential to reach critical mass based 
on local (endogenous) resources such as skilled labour, natural resources, clusters, $\mathrm{R} \& \mathrm{D}$ competence, etc.

The developed model of regional competitiveness assessment (Figure 3) is a component of a broader model developed for the implementation of the entrepreneurial discovery process in the Silesian Voivodeship. Its first part covers analyses of statistical data and indicators so that it is possible to identify sources of economic, scientific and technological advantages which may determine the existence of smart specialisation and competitiveness of the region.

The logical steps applied in the model are a result of gradual processing of data and indicators on the state of the economy, technology and science in the region. Going through these steps makes it possible to identify those sectors which will be the driving force for the competitiveness of the region both at present and in the future. The model consists of three steps:

1. indication of sectors of assumed competitive advantage in the economy, technologies and R\&D sphere,

2. identification and analysis of relations between economy, science and technology,

3. indication of thematic areas for in-depth expert analyses (implementation of the process of entrepreneurial discovery). 


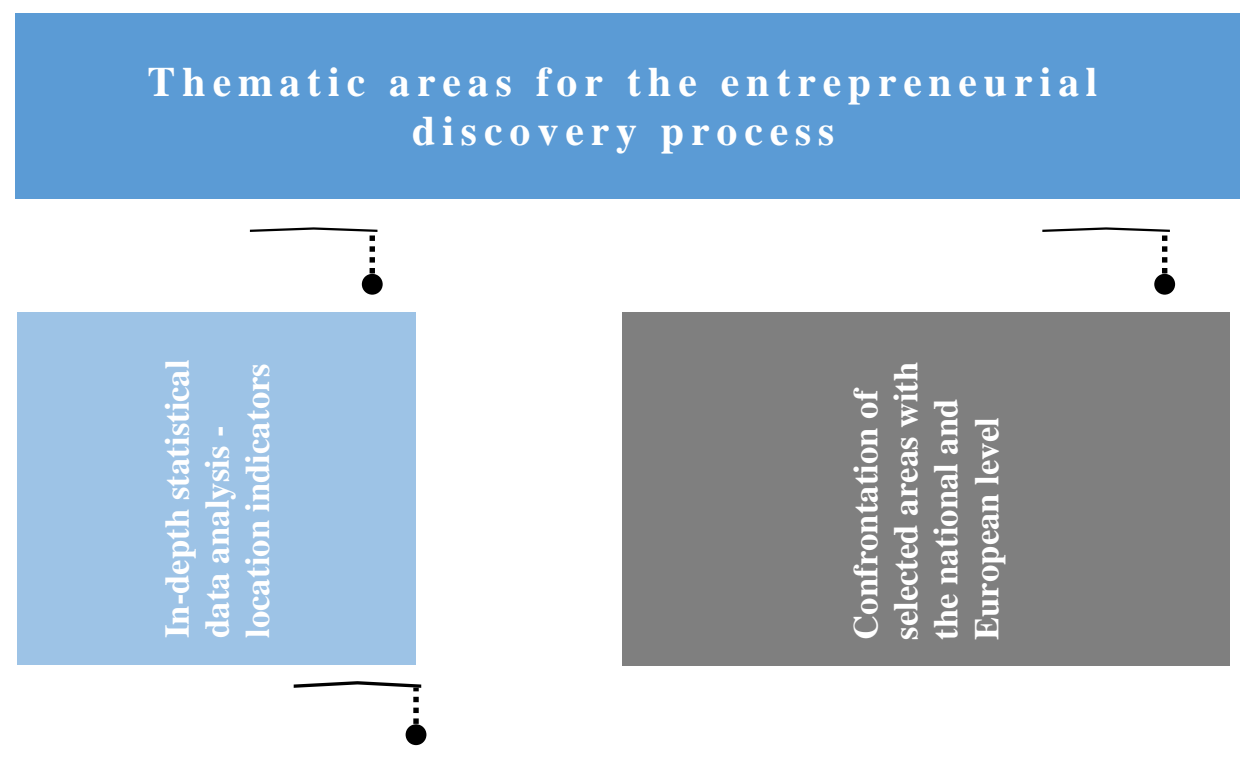

Outline of sectors and areas of advantage
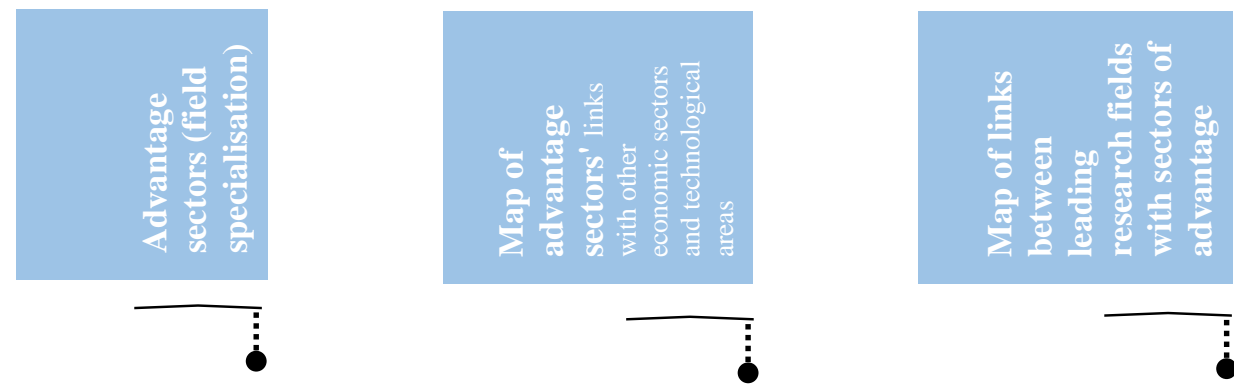

Conversion maps and regional inter- branch flow matrices
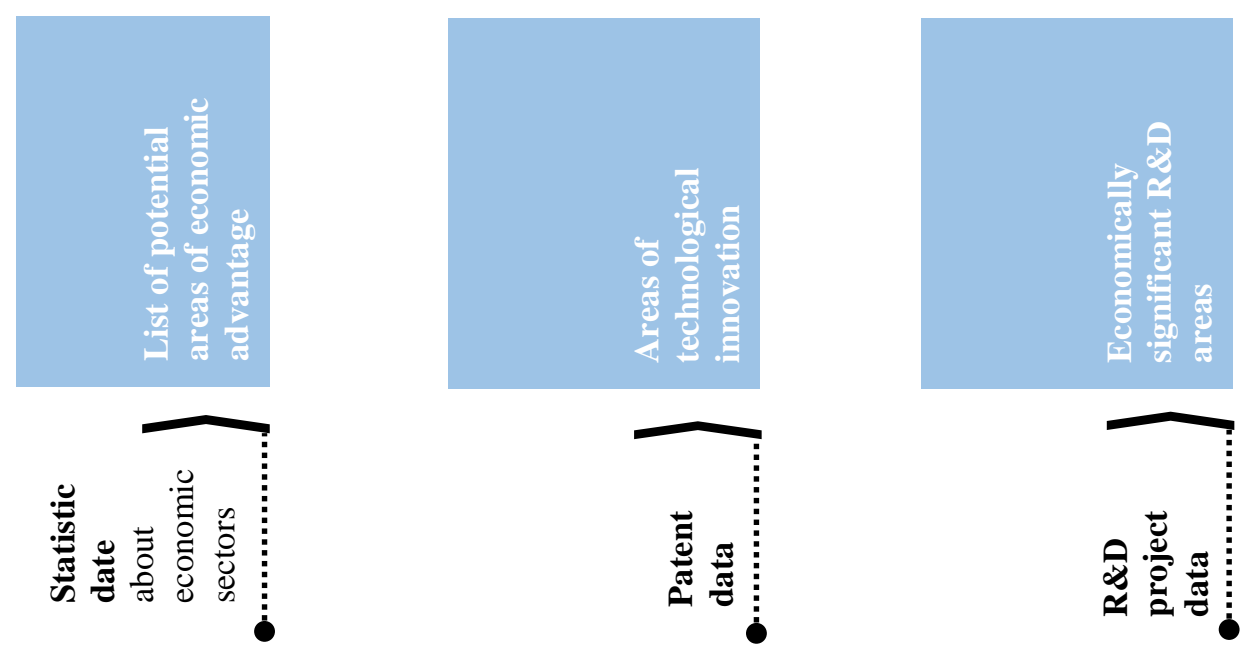

Figure 3. The competitiveness assessment model as a logical step in the analysis of data and indicators Adapted from: own study. 


\section{Statistical data necessary for the assessment of competitive advantage}

Assessment of the competitive advantage of the region and selection of the area of specialisation based on it requires the use of statistical data that describe the economic potential and innovativeness of the region (Cherchye, 2001). The review of the availability of statistical data necessary for the competitiveness assessment is based on the following publicly available databases:

- databases and publications of the Central Statistical Office (including publications and reports), among others, Local Data Bank, STRATEG Development Monitoring System,

- database of the Information and Communication Portal (PIK),

- database of the Polish Patent Office,

- POL-on database (The Integrated System of Information on Science and Higher Education),

- Eurostat database.

The review of the availability of data related to the economic potential of the region has led to the following findings of indicators/data that can be used to assess competitive advantages:

- data on the voivodeship's economy sectors at the level of division, group and class of PKD 2007 are necessary,

- time series: optimal data from the last 10 years and a minimum of 5 years,

- apart from the data from the voivodship level, the relevant data from the national level should also be taken into consideration in order to position the potential of the area/sector in relation to other voivodeships.

In the next step, from a series of collected data, a number of data have been selected which, due to their importance and aggregation method, constitute an integral part of analyses allowing to identify sectors of the economy with a probable competitive advantage in the region. These are:

- entities by sections and divisions of PKD 2007 and ownership sectors,

- entities newly registered by sections and divisions of PKD 2007 and ownership sectors,

- entities deregistered by sections and divisions of PKD 2007 and ownership sectors,

- structural statistics of companies according to PKD 2007 - local entities and number of employed people,

- financial results by section of PKD 2007 — revenues from all activities,

- gross value added according to the section of PKD 2007.

Analysis of available data in the Local Data Bank of Statistics Poland database (LDB) enables to identify areas/sectors of advantage in an inaccurate way, due to the non-uniform way of aggregation and limited to the level of PKD division. However, in order to assess competitive advantages it is essential to rely on data presented in a uniform aggregation system, the minimum requirement is data at the level of PKD division (2-digit PKD code) and 
preferably at the level of PKD classes (4-digit PKD code). It is also very complicated to make an assessment when data cannot be made available due to statistical confidentiality (UoSP, 1995). The finally formulated list of data and statistical indicators to assess competitive advantages, especially in the economic area includes:

1. Gross value added (current prices) [PLN].

2. Gross revenues from sales of products (goods and services) [PLN].

3. Service sector companies that have introduced product and process innovations in the total number of companies [\%].

4. Service sector companies that have introduced marketing and organisational innovations in the total number of companies [\%].

5. Industry sector companies that have introduced product and process innovations in the total number of companies [\%].

6. Industry sector companies that have introduced marketing and organisational innovations in the total number of companies [\%].

7. Number of R\&D employees with ISCED education 5+ [persons].

8. Total number of employed persons with ISCED education 5+ [persons].

9. Net revenues from sales of products (products and services) [PLN].

10. Net revenues from sales of goods and materials [PLN].

11. Net revenues from export sales of goods and materials [PLN or \%].

12. Net revenues from export sales of products (products and services) [PLN or \%].

13. Import of raw materials, materials and semi-finished goods for production purposes [PLN or \%].

\section{Conclusion}

The article describes the concept of determining the competitiveness of the region which should, first and foremost, incorporate data and statistics as well as indicators. It is nowadays hard to identify the sources of competitive advantages of the region without data on its endogenous potential that is included in the statistical information. The presented considerations on the competitiveness of regions indicate that it is a complex and multifaceted construct in which relying solely on statistical data is insufficient. Identification of sources of competitive advantages of the region also demands an efficient interpretation and expert apparatus whose role is played by the processes of entrepreneurial discovery. The information about the region provided in the form of evidence is processed by heuristic methods into prospective visions of regional development. The developed model of competitiveness assessment has found a practical application in the Silesian Voivodeship where the research is currently being conducted, which will result in areas with special development potential to be 
supported. The growth and development of competitiveness is an important objective of the regional policy and the country. It should be remembered, however, that it is also one of the intermediate objectives. Its execution to the required extent will provide the way to the final objectives of the regional development policy. Consequently, regional policy becomes a part of social policy which, in turn, is a priority in building a high quality of life in the region and increasing its competitiveness.

\section{References}

1. Capello, R., Kroll, H. (2016). From theory to practice in smart specialization strategy: emerging limits and possible future trajectories. European Planning Studies, 24, 8, pp. 1393-1406.

2. Cherchye, L. (2001). Using data envelopment analysis to assess macroeconomic policy performance. Applied Economics, 33, pp. 407-416.

3. Dijkstra, L., Annoni, P., Kozovska, K. (2011). A New Regional Competitiveness Index: Theory, Methods and Findings. European Union Regional Policy Working Papers, 2, http://ec.europa.eu/regional_policy/sources/docgener/work/2011_02_competitiveness.pdf.

4. Foray, D., David, P.A., Hall, B.H. (2015). Smart Specialisation - The Concept. Knowledge Economists Policy Brief, 9.

5. Gorzelak, G. (1997). Przemiany polskiej przestrzenni. In: Podstawy naukowo-badawcze polityki przestrzennego zagospodarowania kraju. Warszawa: Rządowe Centrum Studiów Strategicznych.

6. Góralski, P., Lazarek, M. (2009). Czynniki kształtujące konkurencyjność regionów. Zeszyty Naukowe SGGW, Polityki Europejskie, Finanse i Marketing, 1(50).

7. Hatzichronoglou, T. (1997). Revision of the High-Technology Sector and Product Classification. OECD Science, Technology and Industry Working Papers, 2.

8. Khemani, R.S., Shapiro, D.M., Stanbury, W.T. (1998). Mergers, Corporate Concentration and Power in Canada. Halifax: The Institute for Research on Public Policy.

9. Łaźniewska, E., Chmielewski, R., Nowak, P. (2012). Definicje, modele i studia nad regionalną konkurencyjnością. In: E. Łaźniewska, M. Gorynia (eds.), Konkurencyjność regionalna. Koncepcje - strategie - przykłady. Warszawa: PWN.

10. Martin, R. (2003). A Study on the Factors of Regional Competitiveness. A Final Report for The European Commission. Directorate-General Regional Policy; Bruksela, pp. 11-19.

11. Nowak, P. (2011). Nowy paradygmat rozwoju regionalnego na przykladzie wybranych regionów Europy Zachodniej, rozprawa doktorska. Uniwersytet Ekonomiczny w Poznaniu.

12. Misztal, P. (2009). Wykorzystanie rankingów konkurencyjności do oceny konkurencyjności międzynarodowej gospodarek. In: M. Noga, M. Stawicka (eds.), 
Globalizacja a konkurencyjność w gospodarce światowej. Warszawa: Wydawnictwo CeDeWu.

13. Oughton, C., Landabaso, M., Morgan, K. (2002). The regional innovation paradox: Innovation policy and industrial policy. Journal of Technology Transfer, 27, pp. 97-110.

14. Porter, M.E. (2003). The economic performance of regions. Regional Studies, 37, pp. 549-578.

15. Porter, M.E. (2006). Strategia konkurencji. Metody analizy sektorów i konkurentów. Warszawa: Wydawnictwo MT Biznes Sp. z o.o.

16. Metoda określania endogenicznego potencjatu regionu $i$ kraju $w$ oparciu o model matematyczno-statystyczno-ekonometryczny (2013). Raport z prac w ramach przedsięwzięcia pn. Narodowy Program Foresight - wdrożenie wyników. Katowice: Główny Instytut Górnictwa.

17. Radło, M-J. (2010). Ocena zmian czynników konkurencyjności w ujęciu horyzontalnym: przesłanki polityki wzmacniania konkurencyjności. In: W. Bieńkowski, M.A. Weresa, M.J. Radło (eds.), Konkurencyjność Polski na tle zmian gospodarczych w krajach OECD. Ewolucja znaczenia czynników konkurencyjności. Warszawa: Oficyna Wydawnicza SGH, pp. 567-593.

18. Turok, I. (2004). Cities, Regions and Competitiveness. Regional Studies, 38, pp. 10691083.

19. Ustawa z dnia 29 czerwca 1995 r. o statystyce publicznej (Dz.U. 1995 nr 88, poz. 439 z późn. zm.). 